\title{
Miners' lamp: Memory and the underground through a light installation on
}

\section{Bonsall Moor.}

\begin{abstract}
The historic lead mines of the southern Peak District embody the labour and efforts of miners gone, as well as, reflect the industrial past of the region. In my research, I have come to explore these underground places. In the darkness of the underground, light provides not only the ability to see, but also offers comfort. This paper focuses on the creation and execution of a temporary five-day light art installation, named Miners' Lamp, on Bonsall Moor within the Peak District National Park. Inspired by my subterranean explorations and immersive research, the Miners' Lamp engages the local community and encourages a reconsideration of the 'hidden' labour landscapes on the moor. The installation works with the ideas of darkness, light, memory, and the underground showcasing the practice of geography and art in a rural setting and speaking to the politics of preservation through a different aesthetic.
\end{abstract}

\section{Keywords}

Underground, mining landscapes, light installations, land art

\section{Introduction}

Scattered across the moors of the southern Peak

District there are to be found the industrial remains of a thousand years of lead-mining. Slag hillocks, miners' coes and ruined engine houses are as common as moorland pastures. Underground, intricate networks of adits, tunnels and shafts warren their way through limestone rock. Only the most intrepid of potholers and cavers come to know these subterranean worlds. ${ }^{1}$ I was inspired to design new means to connect industrial remains above ground with the hidden mines beneath. This paper reports on efforts to connect geographies of darkness and the underground, and artistic appreciation and public engagement. ${ }^{2}$

The Miners' Lamp was a week-long night-time light installation on Bonsall Moor, Derbyshire in the southeast edge of the Peak District National Park (Figure 1). The project was a collaborative initiative between a local landowner, village residents, and researcher bringing to attention the extensive network of mines and the subterranean geographies crisscrossing below the surface. ${ }^{4}$ It was created as part of research on the development and perceptions of the historic lead mining region of the Peak District and inspired from one of my many excursions underground in the medieval 


\section{Miners' lamp: Memory and the underground through a light installation on}

\section{Bonsall Moor.}

and early modern lead mines. My work reflected upon the integrity of the laboured landscape that is present above and below ground, increasing awareness of the vast infrastructure of mines, tunnels, and shafts that exist within the region. Over time the relevance of mining history has waned and their protection has been limited to only the most significant of heritage sites. ${ }^{5}$ My project aimed to bring these former working places back into the public imagination, creating a new dialogue for the people who now live amongst them- to unforget the mining landscape. In this paper I explore the ideas of underground, darkness, and unforgetting through a temporary landscape installation. ${ }^{6}$ I will review the inspiration behind the installation, covering ideas of the underground and unforgetting, followed by the describing the project location and installation, and ending by offering a sense of community responses from village residents near to the site. [Insert Figure 1 here]

\section{Inspiration}

It is wet, cold, and dark in an underground mine adit, an entranceway chiselled out by miners 200 years in the past. My head torch illuminated the grey limestone walls ahead, otherwise it was dark; a dark that envelops. This pitch of darkness differs from the evening gloom that descended above ground only an hour before. ${ }^{7}$ It is a darkness that seeps into everything, and where without light, vision becomes useless. Your other senses are heightened, touching the wet stone walls and feeling the grittiness of them. Though a bit of fear was present in my thoughts, the darkness was also comforting, a sublime wonder in the mine. ${ }^{8}$ My headlamp and those of my potholing companions bounced off every surface: the muddied floor, the mineral walls, and the perilously interlocked stones overhead that were placed by miners. This shifting between darkness and light allowed for a 'temporary dissolution' from the visual and within this mine I had become part of its space. Exploring by the light of candle, a carbide lamp, or by modern head torch, brings about a physical atunement to the light itself casting different shadows across the walls of the mine. This light was a guide through the remainder of my trip. I turned and wriggled up through another tight spot of the mine, leaning forward clambering along, my fingers brushing the sides of the hand-hewn tunnels. Finally, I approached the mine entrance and with a last heave up, my head popped out of the mine opening. The beam of my head torch caught the flecks of dust and settling fog, penetrating far into the evening sky. A moment of relief followed with a realisation that my light was acting like a beacon announcing the opening, linking the subterranean space with the open skies above. It was that moment of transition in the interstice of 


\section{Miners' lamp: Memory and the underground through a light installation on}

\section{Bonsall Moor.}

the landscape that what I wanted to reveal using light as my guide.

My explorations underground have begun to reveal not only how miners worked but also my own emotional response to these spaces. Being underground exposes a continuum of experience extending from the exploitative and dangerous to comforting and sensual. Early humans lived in caves and underground caverns for most of prehistory, its darkness welcoming and safe, different from the darkness of night outside. ${ }^{10}$ As Williams suggests, the idea of darkness has changed in a European context. ${ }^{11}$ What had once been a ritual and sacred space perceived as a realm out of bounds to human intervention, came to be regarded, increasingly, as a resource that could be legitimately and systematically exploited for the enhancement of human wealth. This change in perception has led to vast tracts of earth being removed for metals, minerals, and oil throughout the world. In Derbyshire, miners and other subterranean labourers endured countless hours underground, clawing away at the earth to recover minerals for use in everyday life. This underground landscape has been refilled, or capped over and forgotten. Today, these relic spaces are explored for recreation, industrial archaeological surveys, or curiosity. This type of exploration has been understood as something akin to an intimate and womblike experience, suggesting complex sensuous relations between the body and the earth. ${ }^{13}$ It is this relationship between the labour of the mining landscape with its exploitative history and the sensual nature of underground exploration that I wanted to spotlight, unforgetting the mines through artful illumination.

\section{Unforgetting}

Unforgetting is not another way to say remembering, but about moving beyond it. Forgetting, as Nora discusses, is as much an active part of memory making as remembering. ${ }^{14}$ Therefore to unforget is to return from forgetting where 'the past and present reverberate between each other echoing in signs and excess signification.' 15 The unforgotten is something that cycles through being forgotten and then slowly cobbled together, assembled from distinct memories. The mining landscape is in the process of unforgetting when inhabited, explored, and walked by the people. Its spaces, stone walls, vegetation, mines, tunnels, evoke a retelling of the past upon the path walked. Such is this installation, where the lights connect above and below ground together, creating an imagined landscape. The imagined landscape is thinking beyond perception and representation, where in imagining landscape the mind continually remakes a place. ${ }^{17}$ In creating this installation, I 


\section{Miners' lamp: Memory and the underground through a light installation on}

\section{Bonsall Moor.}

wanted to reconnect the working life of the mines with atmospheres apparent to the eye above ground.. The installation would require a connection with the villagers and the land, thus my choice for the installation on Bonsall Moor.

\section{Location}

The fields on Bonsall Moor are a bit more unkempt and rough around the edges. Over centuries these fields supported subsistence farming where tending for livestock and lead mining went hand in hand. These fields are full of grass covered lead slag hillocks that show only a glimpse of what was at one point an industrial site (Figure 2). Two remnant rusted cranes lie haphazardly, one precariously standing on the edge of a five metre open cut section of earth, the other collapsed under its own weight. This field was first excavated in the middle of the sixteenth century and named Whitelow Mines. ${ }^{18}$ The mines form part of a larger network of mining claims that stretch across about half a kilometre following the short veins of lead or scrims that lay relatively close to the surface. The land is scarred with open cuts gullied into the limestone, as well as, a scatterplot of capped mine shafts. (Figure 3) The openings are no more than a metre and a half in diameter yet can reach depths of almost thirty metres; in winter they are most noticeable when warmer air beneath vaporises at the surface on cold mornings. Miners slowly excavated the mine shafts until the mineral vein was reached, removing the galena by pick-axe and bringing it to the surface. ${ }^{19}$ Repeating the process left behind a pockmarked landscape, littered with hundreds of mine shafts and an extensive network of chambers below.

Throughout the eighteenth and nineteenth century these mines would be worked until either easier sources of lead were found or the mine became 'dead'. During the twentieth century, this mining field had its gangue worked over for fluorspar and other minerals; hence, the remnant cranes on the surface. ${ }^{20}$ Today, the mines lay dormant; the majority of the mineshafts capped with concrete railroad sleepers hiding its depths below. [Insert Figure 2 here] [Insert Figure 3 here]

\section{Installation}

The week chosen for the installation coincided with the annual village carnival, providing a social setting in which to set my installation and advertise it. Walking the site, getting to know its hillocks, I chose Whittelow Mines for its proximity to a small country lane allowing for public viewing as well as access to the fields. Five mineshafts were selected with regards to their safety, their spatial arrangement, and the workings underneath. To create the desired effect, the lighting needed to be bright, condensed beams, portable, yet not requiring an outside power source, and most importantly, 


\section{Miners' lamp: Memory and the underground through a light installation on}

\section{Bonsall Moor.}

minimally impacting the mining field as the site is within National Park boundaries and

Overhead a bright shooting star recognised as a historic site. ${ }^{21}$ Each light beam was constructed out of three high-powered LED torches attached within a $30 \mathrm{~cm}$ long section of $110 \mathrm{~mm}$ diameter plastic waste water pipe.

\section{Carrying the lighting kit onto the site} walking the fields in the darkness with only my head torch to guide me, I was quickly transported to another place. Out on the field, the darkening and evening light of a summer's day, the moor was alive with the sounds of bleeting, wind blowing over the grass, and the low murmur of Longcliffe Quarry rumbling in the background, provided the perfect wildtrack to the installation. The field at that this time was completely different from the day, its shadows flattening the scene, with a glowing aubergine and sulphur coloured sky beyond. ${ }^{22}$ Opening the gate to the field, I walked onto the damp grass, skirting the nettle patches. Slowly growing accustomed to the dimming light, the hillocked field seemed larger, and the open cast pits even deeper. Manoeuvring around the site, I carefully switched each light on; one torch, and then a second, and finally a third casting a beam brightly into the sky. Four more times, I laid the homemade light beams upon the concrete sleepers over the mines and stepping away each beam came to life on the field. (Figure 4) [Insert Figure 4 here]

streaked across the field, glowing white and bright orange, until burning out in a cerulean glow upon the field of five beams of light. The summer sun having already set into the late night left a purple hue to the west with stars in the darkness above. As my eyes adjusted, the lights picked up the particles in the air as their beams shot into the sky at slightly different angles, amplifying the uneven surface of the field. Two friends who had come along were entranced by the quiet stillness that the lights exuded. To me, they re-presented the surficial interface between underground and atmosphere. We walked onto the farm lane and the lights could be seen from about half a kilometre, beams fading towards the darkness.

'Darkness', 'light', 'pinpoints', 'constellations', 'fields', 'array': such were the responses uttered by visitors during the five-day installation. Standing from that lane the light beams reminded a local villager of a constellation, like Cassiopeia that was brightly shining just overhead-a constellation on the moor. Another viewer said that it reminded them how the earth was alive and something underneath was emerging, as if the T'owd Man had returned. ${ }^{23}$ Others had no idea that the mines were there or felt unease at the realisation that mineshafts punctuated the moor. All of this 


\section{Miners' lamp: Memory and the underground through a light installation on}

\section{Bonsall Moor.}

from five mineshafts lit at their points of intersection with the surface. These five beams became more than just lights, they became spatial points of memory, recalling the workings below and the memory of past eraunforgetting the mining landscape within. The villagers created an imagined landscape where the historic lead mining works could be reasserted and re-preformed within the landscape.

\section{Funding}

Miners' Lamp was funded in part by the Arts in the Derbyshire Dales Scheme.

\section{Notes}

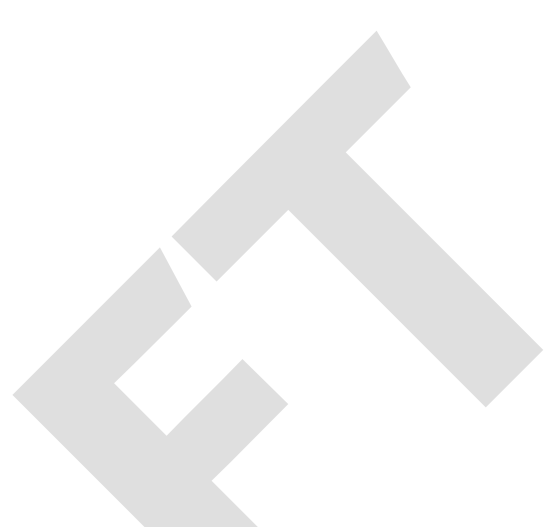

\footnotetext{
${ }^{1}$ Existing work on mining and geographies include: R. Wheeler, 'Mining memories in a rural community: Landscape, temporality and place identity', Journal of Rural Studies, XXXVI (2014), pp. 2232; M. Roe, 'Lead Mining Archaeology in the Yorkshire Dales', Landscapes, IV(2003), pp. 65-78; J. Edwards \& J. Llurdés i Coit, 'Mines and quarries: Industrial heritage tourism', Annals of Tourism Research, XXIII (1996), pp. 341-63; , G. Humphrys, 'Dealing with dilemmas: industrial landscapes in South Wales', Landscape Research, XI (1986), pp. 11-14.

${ }^{2}$ See the cultural geographies special issue 'Geographies of Darkness', particularly T. Edensor, 'Introduction to geographies of darkness', cultural geographies, XXII (2015), pp. 559-565.

${ }^{4}$ C. DeSilvey, 'Memory in motion: soundings from Milltown, Montana', Social \& Cultural Geography, XI (2010), pp. 491-510.
}

5 . J. Barnatt \& R. Penny, The Lead Legacy: The prospects for the Peak District's Lead Mining Heritage. (Peak District National Park Authority, English Heritage, and English Nature, 2004). The regional group, Peak Disrict Mines Historical Society (PDHMS) has for the last fifty years maintained a vested interest in the history of the lead mines of the region. There is limited knowledge of the mines outside of this group of people.

${ }^{6}$ Similar work on darkness and light include N. Morris, 'Night walking: darkness and sensory perception in a night-time landscape installation', cultural geographies, XVIII (2011), pp. 315-42.

${ }^{7}$ T. Edensor, 'Reconnecting with darkness: gloomy landscapes, lightless places', Social \& Cultural Geography, XIV (2013), pp. 446-65. 


\section{Bonsall Moor.}

${ }^{8}$ R. Sorensen, 'We see in the dark', Nous, XXXVIII (2004), pp. 456-80. See also O. Dunnett, 'Contested landscapes: the moral geographies of light pollution in Britain', cultural geographies, (2014), pp.1-18.

${ }^{9}$ Minkowski (1993) cited in C. Bishop, Installation Art: A Critical History (London, Tate Publishing, 2005) p. 82.

${ }^{10}$ R. Williams, Notes on the Underground, (Cambridge, MA, MIT Press, 1990), p.8.

${ }^{11}$ Williams, Underground, pp. 54-56.

${ }^{13}$ S.G. Cant, 'The Tug of Danger with the Magnetism of Mystery': Descents into the Comprehensive, Poetic-Sensuous Appeal of Caves, Tourist Studies, III (2003), p. 68.

${ }^{14}$ P. Nora, 'Between Memory and History: Les Lieux De Mémoire', Representations, XXVI (1989), pp. $7-24$.

${ }^{15}$ K. Stewart, A Space on the Side of the Road: Cultural Poetics in an 'Other' America, (Princeton, Princeton University Press, 1996) p. 75.

${ }^{17}$ J. Nancy, The Ground of the Image, (New York City, Fordham University Press, 2005) pp. 51-62. See also Vergunst, J., 'Seeing Ruins: Imagined and Visible Landscapes in North-East Scotland', in M. Janowski \& T. Ingold (eds), Imagining landscapes : past, present and future, (Ashgate Publishing, Farnham, 2012), pp. 19-37.

${ }^{18}$ J. Barnatt \& R. Penny, The Lead Legacy, Appendix C, p. 86. Based on Rieuwerts, J. H. The Whitelow Mines, Bonsall Moor. (Bakewell: PDNPA Cultural Heritage Team archive, 1993) - Unpublished report for English Heritage.

${ }^{19}$ Galena is the name given to lead ore once removed from the earth. It contains a mixture of lead, zinc, and silver minerals within it.

${ }^{20}$ Gangue is the mineral rock that is left over by miners after removing the galena from it. It usually contains remnant minerals like fluorspar, calcite, and barytes.

${ }^{21}$ J. Barnatt \& R. Penny, The Lead Legacy, p.86.

${ }^{22}$ T. Edensor, 'Reconnecting with darkness: gloomy landscapes, lightless places', Social \& Cultural Geography, XIV(2013), pp. 446-65

${ }^{23}$ The T'owd Man is the name attributed to a small stone bas-relief panel located in St. James Parish Church, Wirksworth that represents the spiritual embodiment of the region and the mining landscape. However, the name stems from a contraction of 'the Old Man', a miners' term meaning abandoned or old workings of a mine. See A. Henstock, T'owd Mon wor frum Bonser: The Origins of the Medieval miner's effigy in Wirksworth church, Mining History: The Bulletin of the Peak District Mines Historical Society, XIV(1999), pp. 68-9. 